\title{
Olive oil: a review on the identity and quality of olive oils produced in Brazil
}

\author{
Paula Freitas Filoda ${ }^{1}$, Fabio Clasen Chaves $^{2}$, \\ Jessica Fernanda Hoffmann ${ }^{3}$, Cesar Valmor Rombaldi ${ }^{4}$
}

\begin{abstract}
The sensory quality of olive oils is influenced by the diversity and concentration of volatile and non-volatile compounds that vary according to cultivar, and edaphic, climatic, and cultivation conditions, which allows for establishing the origin of the product. In addition, since this crop has been recently introduced in Brazil, little is known about the performance of cultivars in this region, where investments in this activity have been made. Thus, relevant aspects about the chemical and sensory quality of olive oils are presented and discussed, as well as how these aspects influence the identity of the product. Index terms - Brazilian olive oil, volatile compounds, chemical composition.
\end{abstract}

\section{Azeite de oliva: uma revisão sobre a identidade e a qualidade de azeites produzidos no Brasil}

Corresponding author:

fabio.chaves@ufpel.edu.br

Received: November 29, 2020

Accepted: April 20, 2021

Copyright: All the contents of this journal, except where otherwise noted, is licensed under a Creative Commons Attribution License.

\begin{abstract}
Resumo - A qualidade sensorial dos azeites é influenciada pela diversidade e concentração de compostos voláteis e não-voláteis, que variam conforme a cultivar e as condições edafoclimáticas e de cultivo, o que permite estabelecer a procedência do produto. Além disso, por se tratar de uma cultura introduzida recentemente no Brasil, pouco se sabe sobre o desempenho das cultivares nas regiões onde o investimento nessa atividade vem sendo feito. Dessa forma, são apresentados e discutidos, nessa revisão, aspectos relevantes sobre a qualidade química e sensorial dos azeites de oliva e como esses aspectos influenciam a identidade do produto.
\end{abstract}

Termos de indexação: azeite de oliva brasileiro, compostos voláteis, composição química.

${ }^{1}$ M.Sc., Graduate Student at Department of Agro-Industrial Science and Technology, Federal University of Pelotas, Pelotas-RS, Brazil. Email: paulaffiloda@hotmail.com (ORCID: 0000-0002-6127-7789)

${ }^{2} \mathrm{Ph} . D$., Professor at Department of Agro-Industrial Science and Technology Federal University of Pelotas, Pelotas-RS, Brazil. Email: fabio. chaves@ufpel.edu.br (ORCID: 0000-0002-5773-0800)

${ }^{3}$ Ph.D., Professor at Technological Institute in Food for Health, University of Vale do Rio dos Sinos, São Leopoldo-RS, Brazil. Email: jessica. hoffmann@outlook.com.br (ORCID: 0000-0002-9185-3820)

${ }^{4}$ Ph.D., Professor at Department of Agro-Industrial Science and Technology, Federal University of Pelotas, Pelotas-RS, Brazil. Email: cesarvrf@ ufpel.edu.br (ORCID: 0000-0002-6995-2937) 


\section{Introduction}

Extra-virgin olive oil is widely appreciated by consumers as a consequence of its sensory attributes and health benefits (APARICIO et al., 2012; BAJOUB; SÁNCHEZ-ORTIZ et al., 2015). According to data from the International Olive Council (IOC), both olive oil production and consumption have grown considerably in areas outside the Mediterranean region, mainly in the United States, Australia, Canada, Chile, Uruguay, Brazil, Japan, and China (IOC, 2020), and this is due to the fact that it is a food product widely reported as beneficial to health (GUASCH-FERRÉ et al., 2020) and a part of different culinary profiles, from the most classic to more recent trends, such as vegetarian and vegan diets (MENAL-PUEY et al., 2019).

In Brazil, olive growing occupies about 7,000 hectares, of which 4,500 hectares are cultivated in Rio Grande do Sul and about 2,000 hectares in the "Serra da Mantiqueira" region, which encompasses areas of the states of Minas Gerais, São Paulo, and Rio de Janeiro (KIST et al., 2019). The cultivation of olive trees (Olea europaea L.) is expanding in Espírito Santo, which currently has 186.5 hectares and expects further investments. In addition, in "Chapada Diamantina" (Bahia), the first 1.6 tons of olives were harvested in 2021, totaling 280 liters of oil (SANTO, 2019; MINAS, 2021). Rio Grande do Sul accounts for the vast majority of the area planted with olive trees in Brazil and also for the largest olive oil production. In the 2019 harvest, 180 thousand liters of olive oil were produced, $75 \%$ more than in the previous year. However, the 2020 harvest was affected by climatic factors, which caused $57 \%$ reduction in the total production of olives in many orchards of Rio Grande do Sul (IBRAOLIVA, 2020).

In addition to the increase in olive oil production and consumption, there is a trend in consumer buying habits, which show greater concern about traceability, authenticity, and quality of olive oils, so that greater value is given to products that are associated with a specific location (geographical indication) and/or special means of production (BAJOUB et al., 2018). In this context, the aromatic profile of olive oils is of great interest, since numerous volatile organic compounds (VOCs) including aldehydes, alcohols, esters, ketones, terpenes, among others, have been described as indicators of sensory quality (DA SILVA et al., 2012; BAJOUB; SÁNCHEZORTIZ et al., 2015). In addition to influencing the sensory characteristics of olive oils, VOCs authenticate the geographical origin of this type of product, since the profile and abundance of these compounds may vary depending on the environmental conditions characteristic of each region and cultivar (PROCIDA et al., 2005; CAJKA et al., 2010; BAJOUB; SÁNCHEZ-ORTIZ et al., 2015).
In addition to volatile compounds, phenolic compounds also influence the sensory characteristics of olive oils and can be used as quality markers. Phenolic compounds such as elenolic acid, ligstroside aglycone, oleuropein aglycone and acetoxypinoresinol allow discriminating oils from different geographical regions (OUNI et al., 2011). On the other hand, the composition of fatty acids seems to be more dependent on the cultivar than on the cultivation conditions or production region (LANTERI et al., 2002).

Thus, scientific knowledge about the chemical and sensory quality of Brazilian olive oils is essential, since production is recent and little is known about the quality of Brazilian commercial olive oils. The knowledge about its composition allows producers to strengthen the identity of the regional product and position their products in the market with distinctive signs. As a matter of fact, Brazilian olive oils have received international awards for their outstanding sensory quality. In addition, as it is a recently introduced crop (mid-2003) (KIST et al., 2019; CAYE et al., 2020), little is known about the performance of cultivars in this new growing region (outside the Mediterranean region). Within this context, in this review, the relevant aspects about olive growing in Brazil, the production of olive oils and the chemical and sensory quality of olive oils and how these aspects influence the product identity will be presented and discussed.

\section{Olive growing}

Olive growing occupies sixth place in the world production of vegetable oils, and the Mediterranean Basin region represents approximately $90 \%$ of the world olive oil production. The main producing countries are Spain, Italy, Greece, Tunisia, Turkey, Morocco, and Portugal. However, olive cultivation has been progressively increasing in countries and regions outside the Mediterranean Basin such as Argentina, Australia, Brazil, Canada, Chile, China, Japan, Peru, United States, Uruguay, and West Africa (IOC, 2020). The expansion and intensification of olive cultivation are associated with the perception that olive oil and table olives are healthy foods (Rallo et al., 2018) and versatile for use in international food and gastronomy (KOIDIS; BOSKOU, 2006).

Following this trend, the area cultivated with olive trees in Brazil is around 7,000 hectares, the largest area (4,500 ha) is located in Rio Grande do Sul and in the Serra da Mantiqueira region (2,000 ha), the latter covering areas of the states of Minas Gerais, São Paulo, and Rio de Janeiro. Olive growing has also been taking place, but in smaller areas, in states such as Espírito Santo, Bahia, Santa Catarina and Paraná, in all cases with prospects for expansion (ROYO, 2010; DA COSTA, 2019; FLORIPA, 2019; KIST et al., 2019; SANTO, 2019; MINAS, 2021). 
In Rio Grande do Sul, the most favorable climatic parameters for fruit ripening are observed in the southern half of the state, with temperatures between $25^{\circ} \mathrm{C}$ and $35^{\circ}$ $\mathrm{C}$, within the temperature range considered ideal for the ripening of olives, although the rainfall index is above levels commonly agreed as optimal for the development of the olive tree $(650 \mathrm{~mm})$ (ALBA et al., 2013). In the mountain areas of Rio Grande do Sul and Santa Catarina, the cold hours accumulated during winter favor the dormancy of olive trees (WREGE et al., 2015). On the other hand, in Paraná although the thermal requirements regarding heat and rainfall are met, the low number of cold hours in most of the state is a limiting factor for olive production (SIMÕES, 2016). In the state of Espírito Santo, the "Capixaba" Institute for Research, Technical Assistance and Rural Extension (Incaper) has already identified 150,000 hectares of land suitable for olive cultivation in the mountainous region, with altitude above 900 meters above sea level (DA COSTA, 2019). The fact that the region of Minas Gerais has higher altitudes favors the cultivation of olive trees in the Serra da Mantiqueira region; however, only the southern regions and a small part of the midwestern region of Minas Gerais have climatic characteristics favorable to the cultivation of olive trees (GARCIA et al., 2018; MARTINS et al., 2020).

In the context of the olive oil business, Brazil is the world's second largest olive oil importer, only behind the United States, and has production corresponding to less than $2 \%$ of its domestic consumption. Thus, investment in the sector is promising and the challenge today is to increase production (AGROLINK, 2020). According to the Brazilian Institute of Olive Growing, the Brazilian olive oil production in 2019 was estimated at 230 thousand liters, approximately 180 thousand liters in RS. It is important to observe that Brazilian olive trees are young and have not yet reached their peak production, with only $40 \%$ of the planted area being currently in production. Currently, Brazil grows cultivars Arbequina, Arbosana, Ascolano 315, Coratina, Frantoio, Grapollo 541, Koroneiki, Manzanilla, and Picual, with 'Arbequina' being the predominant one, as it adapts well to the climate and soil of producing regions (KIST et al., 2019). It is in the context of an emerging and vigorous activity, that the production of olives and olive oils appears on the national
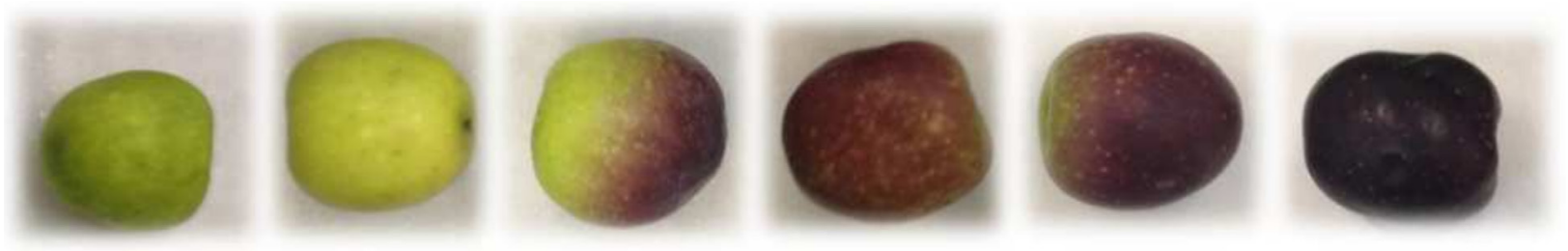

Figure 1. Changes in the olive color during ripening (Source: Filoda, P.F). scenario. Despite the success it has already reached, there are challenges to be overcome, which demand research, knowledge generation, validation and sharing of knowledge, and promotion of the national product.

The perception of traders, associations and regular consumers of olive oils is that products made in Brazil have high quality (SÁ et al., 2019). The construction of the identity of a food product demands, in addition to the production system, a technical-scientific classification in sensory and chemical terms (BAJOUB et al., 2014). In addition, food quality certification is an important requirement in the agrifood sector, as it assures the consumer the conformity and authenticity of products and allows establishing a bond of trust and fidelity in the acquisition of products of proven quality. The characterization of an olive oil increases the added value of the product and promotes its commercialization in both domestic and foreign markets (POULIAREKOU et al., 2011). Although the commercial production of olive oils in Brazil is still recent, the construction of databases on the composition of the products needs to be carried out in order to support future demands for indication of origin (IO) or designation of origin (DO).

\section{Fruit constituents}

The olive tree (Olea europaea L.) is a dicotyledonous angiosperm plant of the Oleaceae family, of arboreal size and native to temperate regions, characterized by two seasons: one cold and wet, in which the plant reaches dormancy, and the other hot and dry, when fruiting occurs. The olive tree fruit is a drupe spherical or elliptical in shape, varying in size and weight ( 2 to $20 \mathrm{~g}$ ) (even on the same tree) and dependent on the cultivar, fruit load, pedoclimatic conditions, and agricultural practices. Anatomically, olives consist of three parts: skin or peel, called epicarp (1.0-3.0\% of the drupe weight), pulp or flesh, also called mesocarp (70-80\% of whole fruits), and the stone, called woody endocarp $(18-22 \%$ of the fruit weight) (BIANCHI, 2003).

Fruit ripening is accompanied by a change in the epicarp color from green to purple (Figure 1), which is related to a progressive decrease in the content of chlorophylls and carotenoids, followed by increase in the content of anthocyanins as the fruit matures (BIANCHI, 2003; LANZA e DI SERIO, 2015; SERVILI et al., 2016). 
The epicarp cells are covered by a cuticle composed of cutin (a polymer almost impermeable to water) and waxes that can be intracuticular or present on the fruit surface and protect internal tissues from mechanical damage and from the attack of fungi and insects. The mesocarp makes up most of the olives and together with the skin, represent the edible portion of olives. Depending on the cultivar and maturation level, its composition is comprised of mainly water (70-75\%) and lipids (14-30\%) (SERVILI et al., 2016).

The lipid fraction of olives, located mainly in the mesocarp, includes triglycerides, phospholipids, and waxes. In general, table olives have lower oil contents, since high levels of this fraction tend to impair the consistency and conservation of the processed fruit (BIANCHI, 2003). Triglyceride content increases with fruit growth and maturation. The fatty acid profile of lipids present in olives is composed of oleic acid (18:1) as the major fatty acid, followed by palmitic acid (16:0), linoleic acid (18:2), palmitoleic acid (16:1), stearic acid (18: 0$)$, and linolenic acid (18: 3), in addition to other minorities whose abundance does not reach $1 \%$ of the total fraction (GÓMEZ-RICO et al., 2009; INGLESE et al., 2011; RALLO et al., 2018). Olives also have organic acids such as oxalic, succinic, malic, and citric acids (1.2$2.1 \%$ of the dry pulp) (SERVILI et al., 2016).

The sugar content decreases during fruit maturation. The main soluble sugars in olives are glucose, fructose, sucrose, and mannitol, although other sugars, such as galactose, mannose, sorbitol, xylose, and rhamnose are also found as structural and reserve components (DROSSOPOULOS; NIAVIS, 1988; BIANCHI, 2003; TAIZ et al., 2017; RALLO et al., 2018). Sugars are related to textural properties (important components of the cell wall, polymerized in the form of pectins and cellulose), in addition to being precursors of oil biosynthesis and providing energy for metabolic changes (MARSILIO et al., 2001; RALLO et al., 2018).

The aspects considered when determining the ideal harvest time include maximization of the fruit size and oil production and quality within a context of efficient orchard management (RALLO et al., 2018). Usually, late fruit harvest results in oils with lower concentration of phenolic compounds and less pronounced aromatic profile (SALVADOR et al., 2001; SERVILI et al., 2015). For example, the contents of the phenolic compound hydroxytyrosol and the volatile organic compound trans2-hexenal (responsible for fruity aroma and green notes) in olive oils obtained from more ripe fruits are lower than those obtained from less ripe fruits (BAJOUB; CARRASCO-PANCORBO et al., 2015; ROMERO et al., 2016). Therefore, olive growers start harvesting earlier in order to obtain high quality olive oils; however, green olives have characteristics that affect technological and rheological properties, in addition to obtaining low oil yield (AGUILERA et al., 2010). Thus, the time for harvesting olives influences characteristics of bitterness, pungency, and oxidative stability of olive oils, and consequently the acceptance of the product by consumers (DAG et al., 2011).

\section{Olive oil production}

Unlike most vegetable oils, olive oil is obtained through mechanical extraction (ANGEROSA et al., 2006). Brazilian legislation defines olive oil as the product obtained only from olive tree fruits, excluding oils obtained through solvent extraction or re-esterification processes and/or any mixture of other oils (BRASIL, 2005). According to Normative Instruction No. 1 of the Ministry of Agriculture, Livestock, and Supply (MAPA), olive oil and olive-pomace oil are categorized according to their identity requirements such as raw material and processes used for obtaining olive oil, and the quality requirements defined in terms of the percentage of free acidity, peroxide indexes, and specific extinction coefficient in the ultraviolet spectrum. Thus, olive oil and olive-pomace oil can be classified into the following groups and types: Virgin olive oil, Olive oil, Refined olive oil, Olive-pomace oil, and Refined olive-pomace oil (BRASIL, 2012). Virgin olive oil is further classified into three types: extra virgin, virgin, and lampante, which is dependent on the quality parameters of free acidity, peroxide index, and specific extinction coefficient in the ultraviolet spectrum (BRASIL, 2012).

The production of olive oil involves a series of stages ranging from the harvest of olives to oil storage. In this process, some of the main stages of the industrial process for obtaining the different types of olive oil are illustrated in Figure 2. Dashed arrows indicate stages of mixtures between the oils that may occur during the process to obtain the final product. 


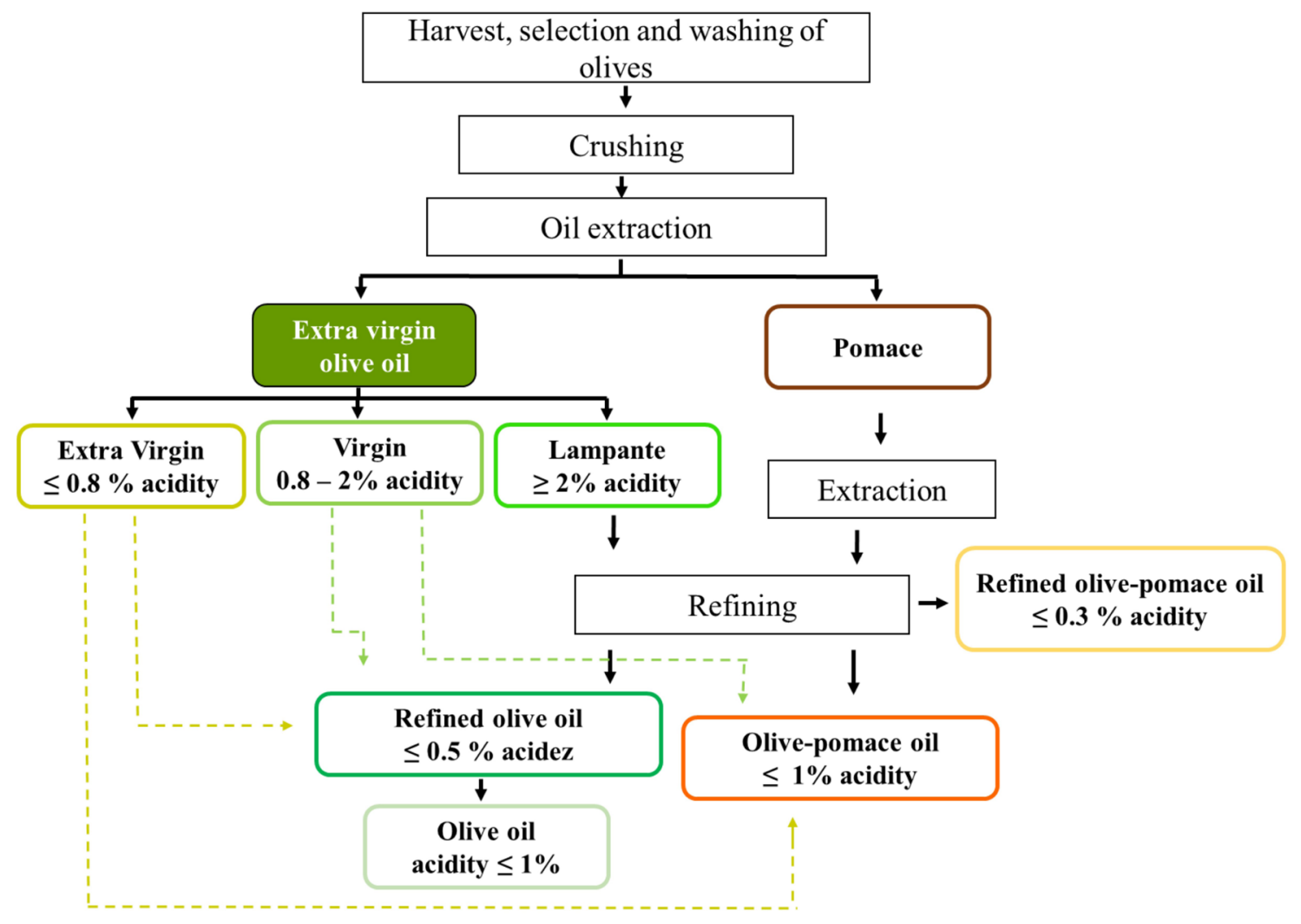

Figure 2. Flowchart showing the processes for obtaining olive oil of different categories (Source: Filoda, P.F).

Once harvested, whether using manual or mechanical methods, olives must be placed in ventilated boxes for transport from the field to the oil press. Olives should be processed as quickly as possible, usually within 24 hours after harvest in order to limit oxidation and biochemical changes. Then, olives are selected for quality, rinsed in running water and weighed to be submitted to crushing and malaxation stages (EPAMIG, 2006; SOUILEM et al., 2017).

The crushing of olives using mechanical hammer crushers is a process used to break the fruit tissues and release the oil contained within the cells. The crushing step is followed by malaxation, an operation that consists of slowly stirring the olive paste obtained to increase the crushing effect, making the paste uniform and breaking the oil/water emulsion, so that oil drops come together to form bigger drops. The malaxation step is carried out in cylindrical mixers (thermomixers), with blades inside that rotate and mix the paste and exert, in a certain way, a scissor effect that cuts the formed paste, considered one of the most crucial stages of the oil extraction process, in which temperature and duration parameters are very influential in the quality and composition of the oil obtained (KAPELLAKIS et al., 2008). At the end of the process, the olive paste derived from the previously mentioned operations, consists of a solid fraction (pomace) and a liquid fraction (oily wort composed of oil and water). The main objective of the remaining stages of the extraction process is the adequate and efficient separation of these phases in order to achieve the greatest possible recovery of the oily phase (BAJOUB, 2016).

For the separation of solid-liquid mixtures, agroindustries commonly use decanter-type centrifuges, where due to the different densities, the high centrifugal forces separate the finely distributed solid particles from the suspension. In this process, a rotating screw conveyor continuously conducts the solid to the discharge. The liquid phase (s) flow (s) along the screw conveyor. Decanter centrifuges are the most modern and widely used method for phase separation (BAJOUB, 2016).

Two-phase and three-phase decanter systems differ mainly in water requirements during the process. Thus, when water is added to the paste to facilitate the extraction process, the system is called three-phase, whereas when oil is centrifuged without adding water, the process is described as two-phase. In a continuous threephase system, three products are generated: oil, pomace, and wastewater. However, the oil fraction obtained still contains water droplets in the emulsion and insoluble solids in the dispersion, and therefore must be submitted to a vertical centrifuge where oil separation and cleaning occurs. In this process, large amounts of wastewater are generated. Although the two-phase system provides two final flows (oil and olive pomace), wastewater continues to be eliminated, but together with the solid portion (MORAL; MÉNDEZ, 2006). 
Filtration is the final stage of olive oil processing, which can be carried out using diatomaceous earth or cellulose to remove suspended solids, as well as moisture before bottling and storage of the final product. Olive oil oxidation, which can start during processing, can be accelerated during the storage stage by exposure to air, heat, light, and metals. Thus, to avoid this problem, olive oil must be stored in dark containers (to prevent exposure to light and oxygen), and kept at about 15-18 ${ }^{\circ} \mathrm{C}$ (BAJOUB, 2016).

Residues obtained from the olive oil extraction process comprise the aqueous residue, composed of water used during the extraction process, in addition to water contained in fruits and water used to wash them and the solid residue, called pomace, composed of pulp and epicarp, parts of the crushed stone and water. Extraction industries seek to invest in alternatives that enable the use of residues, such as composting and mineral fertilization, herbicide, animal nutrition, use of dry pomace for energy generation, and food applications (MEDEIROS et al., 2016).

Due to the costs of olive oil cultivation, harvesting, and extraction processes, in addition to having higher concentration of antioxidant compounds than other oils and exclusive sensory characteristics, olive oil has high market value among vegetable oils, being frequent target of adulteration. In view of the fact that food adulterations often involve replacing high-cost ingredients with cheaper substitutes, fraud involving olive oil by adding other types of vegetable oils of lesser commercial value and of similar composition becomes a major problem both for the industry and for the health of consumers (FLORES et al., 2006; VLACHOS et al., 2006).

\section{Quality parameters}

Brazilian legislation has implemented quality and identity criteria for vegetable oils established by the International Olive Council (IOC) and the Codex Alimentarius Commission (BRASIL, 2005). IOC is an international agency that regulates olive oil by defining quality standards and monitoring authenticity. According to this agency, traditional methods used for detecting adulteration in edible oils include mainly sensory evaluation, chromatography, mass spectrometry, and nuclear magnetic resonance (IOC, 2013). However, although knowledge about the sensory profile of olive oils is relevant to distinguish the quality of products, Brazilian legislation does not require the performance of sensory analysis.
The quality and authenticity of olive oils can be assessed from parameters of free acidity, peroxide index, and specific extinction coefficients, as well as from the composition of fatty acids, sterols, stigmastadienes, and waxes (BRAZIL, 2012). These parameters can be influenced by factors such as maturation, storage, enzymatic action, olive quality, olive oil production system, degree of refining, and purity (BRASIL, 2005; DA SILVA et al., 2012).

The acidity of olive oils comes from the action of lipases that hydrolyze triacylglycerols, releasing fatty acids. The peroxide index measures the degree of oil oxidation, which increases as unsaturated and free fatty acids react with oxygen. Extinction coefficients indicate whether the product comes from good quality raw materials and whether the processing conditions were adequate, since this analysis verify the presence of carbonyl compounds (secondary oxidation stage) and conjugated trienes formed during the clarification stage by oxidation and dehydration of epoxides derived from unsaturated fatty acids (ANGEROSA et al., 2006; AUEDPIMENTEL et al., 2008).

\section{Olive oil composition}

In general, olive oil is basically composed of two fractions: the saponifiable fraction and the unsaponifiable fraction. The saponifiable fraction represents approximately $98 \%$ of the total oil weight, which is mainly composed of triacylglycerols (fatty acids esterified in glycerol) and other minor components, such as free fatty acids, phospholipids, waxes, and esters of sterols. The unsaponifiable fraction, which represents approximately $2 \%$ of the total oil weight, comprises a complex set of compounds belonging to chemical families such as aliphatic and triterpene alcohols, sterols, hydrocarbons, phenolic compounds, pigments, and volatile components (SERVILI et al., 2004; DABBOU et al., 2009). These groups of compounds from the unsaponifiable fraction are essential in the taste and oxidative stability of olive oils and there is evidence of the beneficial health properties provided by some of these olive oil components, including vitamin E, pigments, phytosterols, and phenolic compounds (BAJOUB; CARRASCO-PANCORBO et al., 2015).

Olive oil is distinguished from other oils due to its high content of monounsaturated fatty acids, with oleic acid $(\mathrm{C} 18: 1 \Delta 9)$ being the most abundant, representing 55 to $83 \%$ of total fatty acids (AL-BACHIR; SAHLOUL, 2017). Linoleic (C18: $2 \Delta 9,12)$ and linolenic (C18: 3 $\Delta 9,12,15)$ polyunsaturated acids represent 3 to $21 \%$ and less than $1 \%$, respectively, of the total olive oil fatty acid composition (BRASIL, 2005; MAGGIO et al., 2009; DA SILVEIRA et al., 2017). In addition, olive oil is a product that contains considerable amounts of saturated fatty 
acids in its composition, especially palmitic acid, which can represent up to $20 \%$ of the total olive oil fatty acid composition. Table 1 shows the fatty acid composition of extra virgin olive oils, established by IOC and adopted by Brazilian legislation. However, a certain difference between limits for myristic (less than or equal to 0.05 ) and linoleic (3.5 to 21.0) fatty acids established in Brazil is verified in relation to IOC limits, where the amount of myristic acid must be less or equal to 0.03 and for linoleic acid, the limit is 2.5-21.0.

Table 1. General composition of extra virgin olive oil fatty acids

\begin{tabular}{cc}
\hline Fatty Acids & Established limits (\%) \\
\hline C $14: 0-$ Myristic & Less than or equal to 0.03 \\
C $16: 0-$ Palmitic & $7.5-20$ \\
C $16: 1-$ Palmitoleic & $0.3-3.5$ \\
C $17: 0-$ Margaric & Less than or equal to 0.3 \\
C 17:1 - cis-10-Heptadecanoic & Less than or equal to 0.3 \\
C $18: 0-$ Stearic & $0.5-5.0$ \\
C $18: 1-$ Oleic & $55.0-83.0$ \\
C $18: 2-$ Linoleic & $2.5-21.0$ \\
C $18: 3-$ Linolenic & Less than or equal to 1.0 \\
C $20: 0-$ Arachidonic & Less than or equal to 0.6 \\
C 20:1 - cis-11- Eicoseneic & Less than or equal to 0.4 \\
C $22: 0-$ Behenic & Less than or equal to 0.2 \\
C $24: 0-$ Lignoceric & Less than or equal to 0.2 \\
\hline
\end{tabular}

Source: IOC, 2013

Olive oil composition can vary depending on cultivar, latitude, agricultural techniques adopted, maturation level of olives at harvest, olive oil extraction system and storage conditions (ROMERO et al., 2016). The authenticity of the product and the distinction of oils from different cultivars and geographical origins can be performed based on the fatty acid profile (YOUSSEF et al., 2011; BAJOUB; CARRASCO-PANCORBO et al., 2015; BORGES et al., 2017).

In Brazil, due to the recent olive oil production, little is known about the composition of local products. Studies on the composition of Brazilian olive oils began in 2010, when the physicochemical characteristics of different olive cultivars cultivated in the municipality of Maria da Fé (MG) were evaluated, with the first oils extracted from the region being classified as extra virgin (DE OLIVEIRA et al., 2010). Subsequently, olive oils extracted from cultivars JB1, Ascolano 315, Negroa, 0025 and 0004 cultivated on the Epamig experimental farm, in the municipality of Maria da Fé (MG), were evaluated for characteristics of acidity index, iodine, saponification, peroxides and fatty acid profile. 'Negroa' and 'JB1' showed the highest productivity and the best acidity, saponification, peroxides and iodine rates. In addition, all cultivars showed fatty acid levels within expected limits (CARDOSO et al., 2010). Olive oils from 'Arbequina' grown in southern Brazil, in the municipalities of Caçapava do Sul and Cachoeira do Sul, were evaluated in terms of physicochemical parameters and fatty acid profile. The results of analyses met the required standards, classifying oils as extra virgin (MELLO; PINHEIRO, 2012).
Ballus et al. (2014) evaluated the profile of phenolic compounds, tocopherols and fatty acids from 17 monovarietal olive oils produced at the Maria da Fé (MG) experimental station. Ballus et al. (2015) also evaluated the profile of phenolic compounds of cultivars Arbequina, Grappolo, Koroneiki, and Manzanilha grown in Dom Pedrito and 'Arbequina', 'Coratina', 'Frantoio' and 'Koroneiki' grown in Pelotas. In all cases, it was observed that these oils had high quantity and diversity of phenolic compounds.

The production and yield of olive oils from cultivars Arbequina, Arbosana, and Koroneiki in four locations in Santa Catarina were evaluated in order to obtain more information about the production potential of the crop in that region. In general, cultivars showed good fruit productivity and satisfactory olive oil yield, particularly cultivar Koroneiki (DA CROCE et al., 2016). In a previous study, the physicochemical characteristics of olive oils produced in experimental units of Santa Catarina were evaluated, and the authors reported that 'Koroneiki', 'Arbequina', and 'Arbosana' were adapted to the local edaphic and climatic conditions and were able to produce high-quality olive oils, according to chemical quality parameters required by IOC (DA CROCE et al., 2012). 
The composition of Brazilian oils was also evaluated by Bruscato et al. (2017), who determined the levels of tocopherols, pigments, phenolic compounds, and fatty acids in olive oils produced at the "Embrapa Clima Temperado" (RS) research station. The composition of olive oils from cultivar Arbequina produced in PelotasRS and Maria da Fé-MG was also evaluated in order to compare it with that of oils from the same cultivar produced in Spain (BORGES et al., 2017). More recently, the volatile profile and organoleptic characteristics of olive oils from cultivars Arbequina, Arbosana, Coratina, Grappolo, and Koroneiki produced in Minas Gerais, São Paulo, and Paraná were evaluated (ZAGO et al., 2019). Crizel et al. (2020), demonstrated that harvest and cultivar influence the chemical composition related to the quality of oils produced in Pinheiro Machado, RS.

Among the classes of compounds found in olive oils, phospholipids, found in small amounts in olive oil (usually $<150 \mathrm{mg} / \mathrm{kg}$ ), act as antioxidants in olive oils (KOIDIS; BOSKOU, 2006; ALVES et al., 2016). Olive oils, in general, contain virtually no wax in their composition because they are extracted via mechanical processing. Thus, the presence of waxes can be indicative of fraudulent mixtures containing vegetable oils, since waxes are dissolved in solvents used during the process of extracting oils from other sources (MAILER et al., 2010).

Olive oil also has $\alpha$-tocopherol, a vitamin $\mathrm{E}$ component with antioxidant activity, which contributes to the oil stability and provides health benefits. $\alpha$-tocopherol levels between 117.47 and $325.00 \mathrm{mg} \mathrm{kg}^{-1}$ have been reported in olive oils from six cultivars produced in southern Brazil in the 2017 and 2018 harvests (CRIZEL et al., 2020). The percentage of tocopherols is strongly influenced by climatic factors, agricultural management, maturation level, and cultivar (SERVILI et al., 2009; EL RIACHY et al., 2011; RALLO et al., 2018).

Among pigments responsible for color in olive oil, chlorophylls contribute to the green color while carotenoids to the yellow-orange color. Carotenoids also promote immunological, endocrine and metabolic benefits due to their pro-vitamin A activity. The content of carotenoids in olive oil depends on storage period and conditions as they are susceptible to degradation by exposure to light and high temperatures (RALLO et al., 2018). Monovarietal olive oils obtained in southern Brazil showed pigment levels varying according to cultivar and year of harvest, with carotenoid content between 3.80 and $31.0 \mathrm{mg} \mathrm{kg}^{-1}$ and chlorophyll content between 0.1 and 7.2 mg kg-1 (CRIZEL et al., 2020).
Phenolic compounds are minor constituents in olives comprising $1-3 \%$ of the fresh pulp weight. Synthesized by plants during growth and development in part due to responses to stressors, phenolics can act as antimicrobials, photoprotectors, visual attractants, as a defense against herbivores and pathogens, and as instruments of communication between plants and between plants and the environment (NACZK; SHAHIDI, 2004; KARBAN, 2008). The main class of specialized metabolites typical of the Oleaceae family is represented by secoiridoids, a group of monoterpenoids with a cleaved methylcyclopentane skeleton, the most abundant representatives being oleuropein and ligstroside derivatives (Figure 3) (RYAN; ROBARDS, 1998; ALAGNA et al., 2012).

The class of phenolic constituents influences the nutritional and sensory quality of olive oils, contributing with bitterness, astringency, and pungency. In addition, phenolic compounds present in olive oils prevent lipid oxidation, making the product more stable and with a longer shelf life (SERVILI et al., 2009; DAĞDELEN et al., 2013; BAJOUB; CARRASCO-PANCORBO et al., 2015). Many of these phenolic compounds also have to beneficial effects on human health, with antioxidant, antiinflammatory, and antimicrobial properties, among others (CARRASCO-PANCORBO et al., 2005; MEDINA et al., 2006; CICERALE et al., 2012).

The phenolic fraction of olive oils consists of a heterogeneous mixture of compounds belonging to several families with different chemical structures. These compounds belong to five main classes: (i) phenolic acids (e.g., caffeic and syringic acids), (ii) phenolic alcohols (e.g., hydroxytyrosol and tyrosol), (iii) flavonoids (e.g., luteolin and apigenin), (iv) secoiridoids (e.g., oleuropein and ligstroside) and (v) lignans (e.g., pinoresinol and 1-acetoxypinoresinol) (SERVILI et al., 2009; EL RIACHY et al., 2011; BAJOUB; CARRASCO-PANCORBO et al., 2015). 
The main phenolic alcohols in olive oils are hydroxytyrosol, also known as 3,4-dihydroxyphenyl ethanol (3,4-DHPEA) and tyrosol (also known as p-hydroxyphenyl ethanol or p-HPEA). These alcohols are present at low concentrations in fresh oils, but concentrations increase over the storage period as a result of the hydrolysis of secoiridoids (BRENES et al., 2001; EL RIACHY et al., 2011). During olive oil extraction, oleuropein and ligstroside are enzymatically hydrolyzed to dialdehyde (3,4-DHPEA-EDA, p-HPEAEDA) and aldehyde carboxymethyl (3,4-DHPEA-EA and p-HPEAEA, respectively from oleuropein and ligstroside). Its concentration in olive oil varies considerably according to the management practices adopted, maturation level, geographical region, and oil extraction conditions (MALHEIRO et al., 2015). Table 2 shows the levels of phenolic compounds so far found in Brazilian monovarietal olive oils. Among identified compounds, phenolic alcohols appear as the most abundant group of phenolic compounds among analyzed samples, followed by secoiridoids and flavonoids. Higher levels of coumaric, vanillic, and syringic acids, in addition to compounds such as hydroxytyrosol and luteolin, seem to characterize oils from cultivar Arbequina. In addition, regardless of cultivar, compounds such as oleuropein aglycone and oleacin are among the most abundant secoiridoids found in olive oils (CRIZEL et al., 2020).<smiles>C/C=C1\C(C(=O)OC)=CO[C@H](O[C@@H]2O[C@H](CO)[C@@H](O)[C@H](O)[C@H]2O)C1CC(=O)OCCc1ccc(O)cc1</smiles><smiles>OCCc1ccc(O)cc1</smiles>

The phenolic composition of olive oils is strongly affected by growing conditions (cultivar, production region, planting density, nutrition, water supply, abiotic stresses, among others) and by technological production conditions (CRIADO et al., 2004; RANALLI et al., 2005; SERVILI et al., 2007; TURA et al., 2007). Within this context, olive oils obtained from orchards without irrigation showed higher levels of phenolic compounds compared to irrigated orchards. Nitrogen-rich fertilization seems to reduce the phenolic content. In both cases, regulation of the phenolic composition is influenced by the activity of the phenylalanine ammonia lyase enzyme (PAL) (ROMERO et al., 2016).

Both non-targeted metabolomic analysis and the targeted assessment of the phenolic compound profile have been used to differentiate oils from different cultivars and to reveal discriminating characteristics between oils from different geographical origins and therefore can be used as markers to prove the authenticity of olive oils (DABBOU et al., 2009; BAJOUB, 2016; KALOGIOURI et al., 2016).<smiles>OCCc1ccc(O)c(O)c1</smiles>

Figure 3. Examples of secoiridoids and phenolic alcohols commonly found in olive oils. 


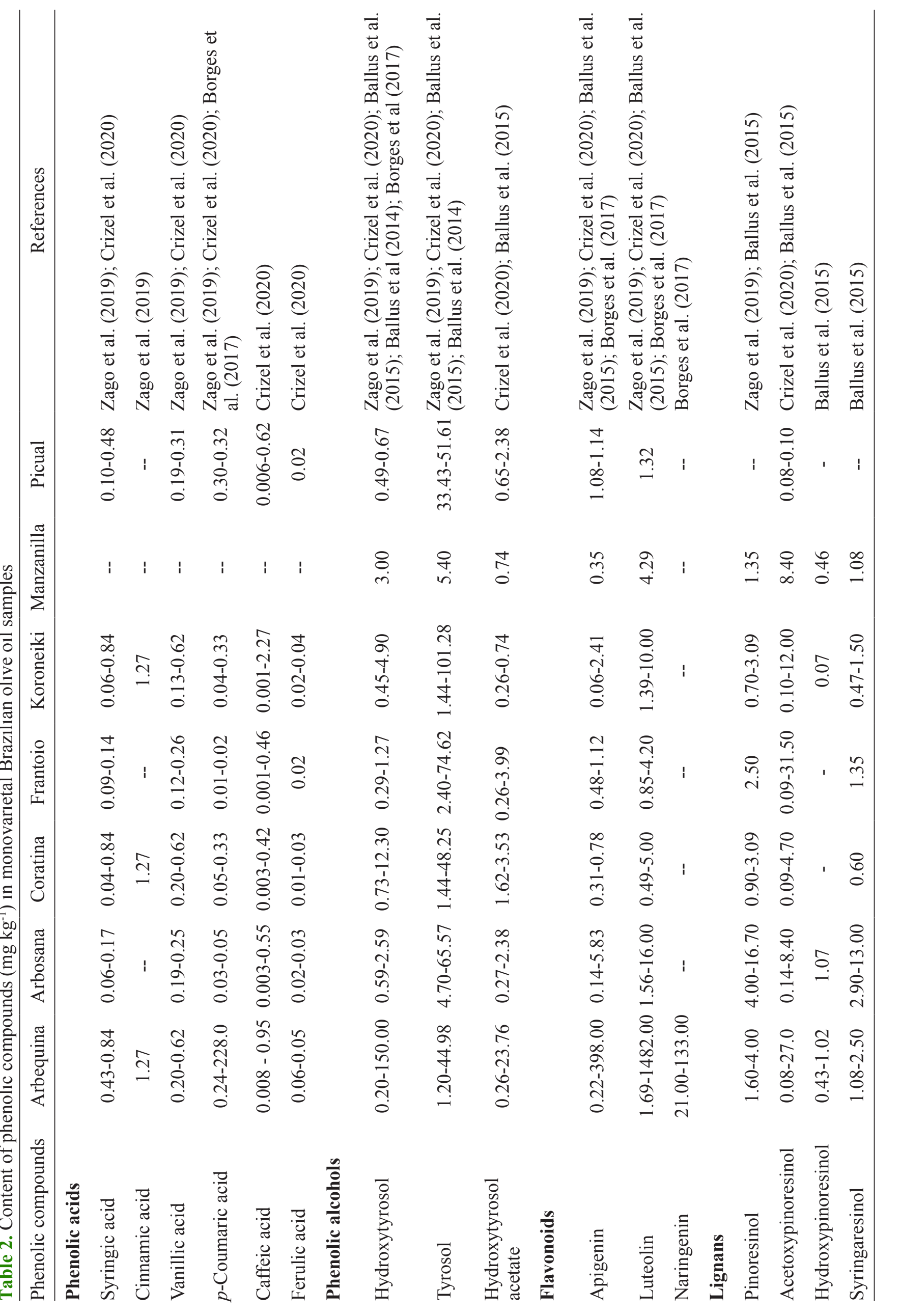




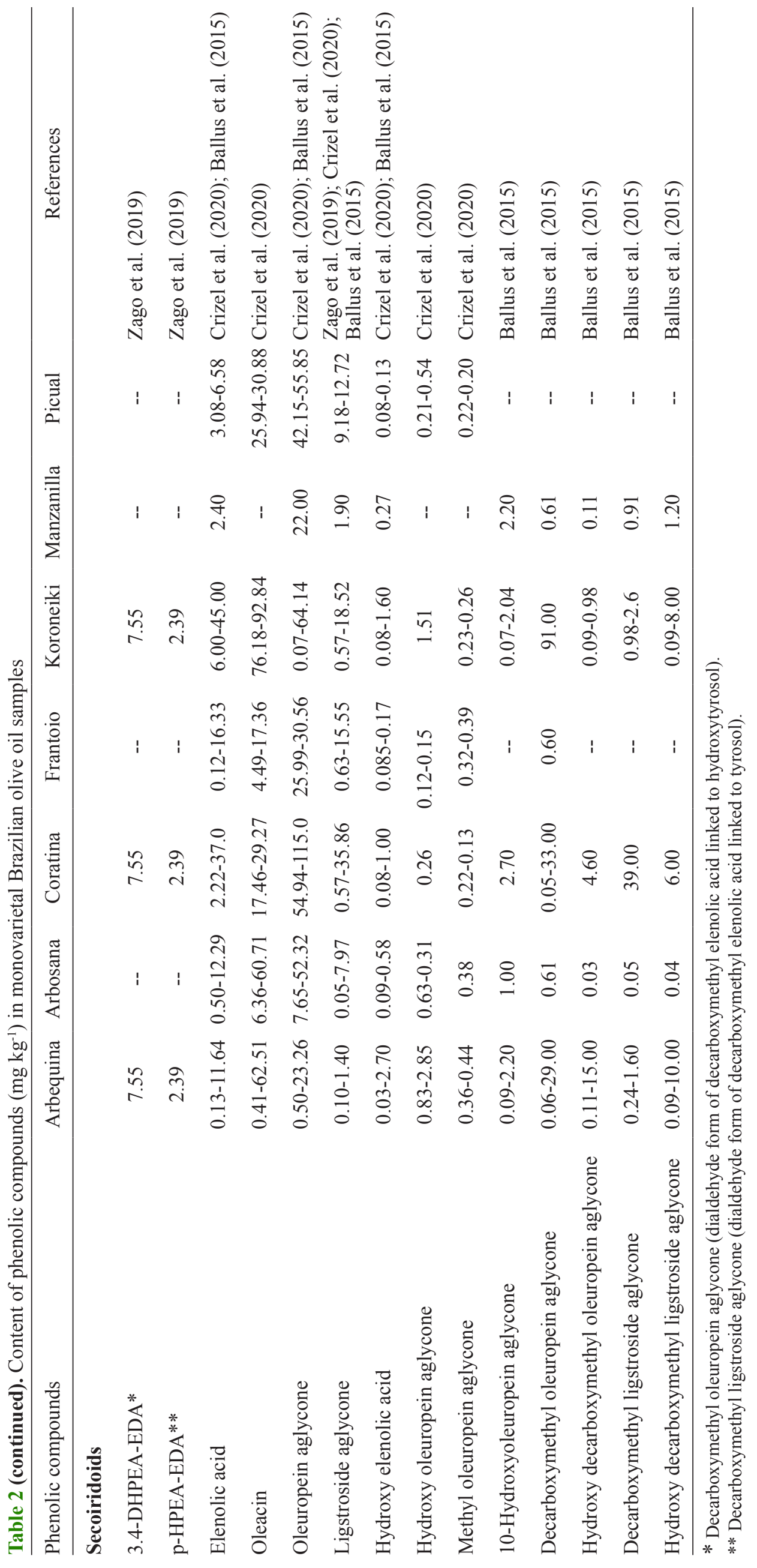




\section{Volatile organic compounds (VOC)}

Regular consumption of virgin olive oil is associated with health benefits; in addition, this type of product is appreciated all over the world for its flavor and aroma, characterized by the presence of various volatile organic compounds (VOCs) from different chemical classes (CECCHI; ALFEI, 2013). Both positive attributes and sensory defects in olive oils can be associated with volatile compounds. The absence of sensory defects is necessary for the product to be classified as extra virgin olive oil (ANGEROSA et al., 1999).

The sensory quality of olive oils is largely related to the perception of aroma, flavor and color, decisively influencing recognition, selection, and acceptability of this type of product by consumers. The perception of aroma in olive oils is the result of a complex sensory interaction between compounds responsible for flavor and aroma and human olfactory and taste receptors (BOSKOU, 2012). Non-volatile components, particularly phenolic compounds, stimulate taste receptors and the free endings of trigeminal nerves, stimulating the perception of bitterness, pungency, and astringency, characteristics considered positive attributes in olive oil (SERVILI et al., 2004; BENDINI et al., 2007).

Aroma is related to a complex mixture of volatile compounds, which also stimulate the olfactory receptors, providing positive or negative attributes to the oil. The peculiar flavor and aroma of olive oils are characterized by a balance between green, fruity, bitter and pungent sensory notes, which provide both the green character and the impression of freshness (APARICIO; LUNA, 2002; AKACHA; GARGOURI, 2009).

VOCs described in literature as aroma components of olive oils are compounds of low molecular weight $(<300$ $\mathrm{Da}$ ) and of different chemical nature, being present at very low concentrations. Such compounds, often fat-soluble and capable of binding to proteins (membrane receptors), volatilize at room temperature, so that, when they reach olfactory receptors, they promote an odor sensation (ANGEROSA et al., 2004; CECCHI; ALFEI, 2013).

VOCs responsible for the aroma of olive oils are derived from the action of lipoxygenase (LOX) on unsaturated fatty acids. Some of the volatile compounds found in olive oils are present in the intact tissue of olives, while others are formed during the disruption of the cell structure during oil processing due to enzymatic reactions in the presence of oxygen. The main precursors of volatile compounds are fatty acids (particularly linoleic and linolenic) and amino acids (leucine, isoleucine, and valine) (LUNA et al., 2006). Valine and leucine can be converted into volatile compounds such as esters and branched alcohols (KALUA et al., 2007).
During oil extraction, in the crushing stage, olive tissues are broken and enzymes are released and end up hydrolyzing triglycerides and phospholipids, releasing free fatty acids. These fatty acids are then oxidized by LOX to form hydroperoxides (9 and 13-hydroperoxides). The generated hydroperoxides are subsequently cleaved by hydroperoxide lyases, leading to the formation of shortchain aldehydes such as hexanal, cis-hexenal and transhexenal (Figure 4) (ANGEROSA et al., 2004; CECCHI; ALFEI, 2013).

Six-carbon aldehydes are unstable and, spontaneously or by enzymatic action, are reduced to alcohols by alcohol dehydrogenase enzymes. These six-carbon alcohols can then be esterified by the activity of alcohol acyltransferase (DUDAREVA et al., 2006; AKACHA; GARGOURI, 2009).

The most abundant compounds that favorably contribute to the aroma of olive oils are aldehydes and alcohols originating from the action of LOX, so that compounds such as aldehydes and alcohols with five and six carbons formed from 13-hydroxyperoxides of linoleic and linolenic acids (e.g., hexanal, cis / trans-hexenal, hexanol, hexenol, acetate esters, pentenol), generally comprise $60-80 \%$ of the total volatile compounds and contribute to the green odor and astringency of virgin olive oils and are associated with some of the positive attributes: "Pungent-sweet-floral", "floral", "apple-green", "grass", and "citrus" (APARICIO; LUNA, 2002; POULIAREKOU et al., 2011).

Compounds formed by fermentation of sugars or transformations of amino acids by exogenous enzymes (usually of microbial activity) and oxidative processes provide negative sensory characteristics compromising the olive oil quality (APARICIO; LUNA, 2002; KALUA et al., 2007; PROCIDA et al., 2016). Volatile components such as monounsaturated aldehydes (7 to 11 carbons), dienes ( 6 to 10 carbons), branched aldehydes (5 carbons), and alcohols or some ketones (8 carbons) can reach relatively high concentrations in oils and are characterized as "off-flavors", that is, volatiles that confer sensory defects or strange flavors (APARICIO; LUNA, 2002; RALLO et al., 2018). 
The contribution of VOCs to the global aroma of olive oils depends not only on their concentration, but also on their sensory threshold values (ANGEROSA et al., 2004; KALUA et al., 2005). In addition, antagonism and / or synergism between different molecules can occur and affect the final flavor of olive oils. Chemical aspects of molecules (volatility, hydrophobic character, size, shape, and conformational structure) and the type and position of functional groups affect the sensory threshold value and, therefore, odor and taste intensity. All these aspects contribute to favor the interaction with receptor proteins and, for this reason, the sensory threshold is more important than its concentration. Thus, highly concentrated VOCs are not necessarily the main odor contributors (ANGEROSA et al., 2004; POULIAREKOU et al., 2011).
The qualitative and quantitative composition of VOCs is strongly dependent on the levels and activity of enzymes involved in the biosynthetic pathway. The production of metabolites also changes in relation to the maturation level, geographic region, and conditions used during olive oil extraction and processing. The content of each volatile compound from the LOX pathway presents a different evolution pattern in relation to the extent of fruit pigmentation; in addition, fruits of different cultivars grown under the same environmental conditions lead to different volatile compound profiles, as well as fruits of the same cultivar produced in different geographic regions (ANGEROSA et al., 1999; KALUA et al., 2007).

Table 3 shows volatile compounds identified in olive oils obtained from cultivar Arbequina produced in different states of Brazil (Minas Gerais, São Paulo, and Paraná) (ZAGO et al., 2019). Thus, it is possible to verify the effect of the environment on the performance of the same cultivar, since the profile and abundance of volatile compounds varied according to the environmental conditions characteristic of each region. In addition to the influence on the sensory characteristics and flavor profile of olive oils, VOCs can potentially authenticate the geographical origin of this type of product in order to identify markers of geographical or cultivar origin.

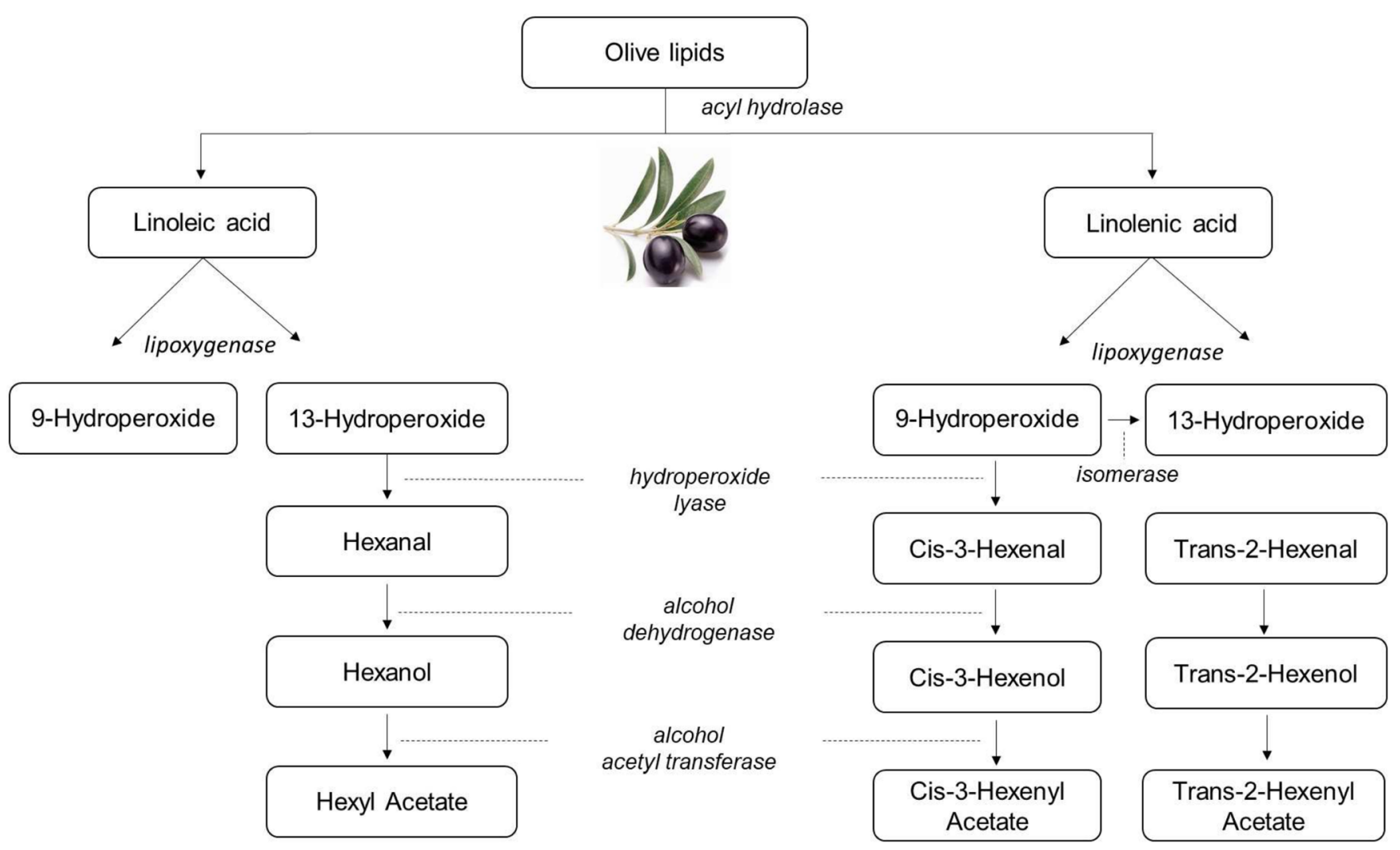

Figure 4. Route for the formation of the main volatile compounds in olive oil and enzymes involved (Source: Adapted from Angerosa et al. (2004)). 
Table 3. Volatile compounds ( $\mathrm{mg} \mathrm{kg}^{-1}$ of olive oil) identified among Brazilian oils from cultivar Arbequina grown in Minas Gerais (MG), São Paulo (SP) and Paraná (PR)*

\begin{tabular}{|c|c|c|c|c|}
\hline Compounds & Contribution to aroma & $\begin{array}{c}\text { Arbequina } \\
(\mathrm{MG})\end{array}$ & $\begin{array}{c}\text { Arbequina } \\
\text { (SP) }\end{array}$ & $\begin{array}{c}\text { Arbequina } \\
\text { (PR) }\end{array}$ \\
\hline \multicolumn{5}{|l|}{ Aldehydes } \\
\hline 2-Methyl butanal & malted & 2.10 & 1.00 & 2.09 \\
\hline 3-Methyl butanal & malted & 1.10 & 1.10 & 2.00 \\
\hline cis-3-Hexenal & green / leaf & 3.76 & 2.16 & 1.23 \\
\hline trans-2-Hexenal & green / green apple / bitter almond & 184.17 & 225.07 & 184.20 \\
\hline trans-2-Pentenal & green / apple / bitter almond & 2.65 & 2.79 & -- \\
\hline Hexanal & green / green apple & 17.45 & 8.53 & 10.19 \\
\hline Nonanal & fat / wax / pungent & 2.10 & -- & 0.95 \\
\hline Total aldehydes & & 213.33 & 240.66 & 200.66 \\
\hline \multicolumn{5}{|l|}{ Ketones } \\
\hline 3-Pentanone & sweet & 9.23 & 5.34 & 3.47 \\
\hline 1-Penten-3-one & green & 9.14 & 13.22 & 8.20 \\
\hline Total ketones & & 18.37 & 18.56 & 11.67 \\
\hline \multicolumn{5}{|l|}{ Alcohols } \\
\hline trans-2-Hexen-1-ol & green / leaves & 17.36 & 7.54 & 5.89 \\
\hline 2-Penten-1-ol & banana & 0.49 & 1.33 & 0.48 \\
\hline Ethyl alcohol & alcohol & 1.07 & -- & -- \\
\hline Total alcohols & & 18.93 & 8.87 & 6.36 \\
\hline \multicolumn{5}{|l|}{ Carboxylic acids } \\
\hline Propanoic acid & pungent / sour & 1.33 & -- & -- \\
\hline Acetic acid & sour / vinegar & 40.55 & 10.99 & 5.38 \\
\hline Total carboxylic acids & & 41.88 & 10.99 & 5.38 \\
\hline
\end{tabular}

* Zago et al. (2019)

In Brazil, sensory analysis is among assessments listed in Normative Instruction No. 01/2012 of MAPA, which establishes identity and quality standards for olive oil. However, the legislation does not require producers to assess the sensory characteristics of their products. In addition to the need for a permanent team of trained panelists, panel testing is an expensive and slow procedure, which is not always available to small and medium-size companies (ROMERO et al., 2015). In addition, only laboratories accredited by IOC are able to carry out such an analysis, and in Latin America, only Argentina and Chile have accredited laboratories. The proposal of validating sensory analysis methods independently, similar to what has been performed for other foods, is a research priority to be considered.
The international method for the organoleptic assessment of olive oils, proposed by IOC, is based on the intensity of defects and attributes perceived by a group of selected and trained panelists. The main positive attributes are fruity, bitter, and pungent, while defects include old, mold, wine, acid, rancid, among others. According to the detection and intensity of these sensory defects, olive oils are classified into extra virgin, virgin, ordinary or lampante categories (IOOC, 2013).

In addition to sensory analysis, many analytical procedures have been used to isolate, identify, and quantify volatile compounds that characterize the aroma of olive oils. The most common analytical method used for the extraction of volatile compounds is solid phase microextraction (SPME). It is a sample preparation technique in which volatile components are adsorbed in a polymeric matrix and later desorbed in the gas chromatography system coupled to flame ionization detector (FID) or mass spectrometry (ANGEROSA et al., 2004; TEMIME et al., 2006). 
The solid phase consists of a fine fused silica fiber covered with polymeric material used as stationary phase in which volatile substances are adsorbed. Fibers with different coatings are available, depending on the type of matrix to be analyzed. In the case of olive oil samples, the best extraction efficiency is obtained by using fibers with coating material composed of three types of material, Divinylbenzene / Carboxen / Polydimethylsiloxane (DVB / CAR / PDMS) (CAVALLI et al., 2003; ANGEROSA et al., 2004). For the collection of volatile compounds, the method consists of exposing, for a determined period (equilibrium time), the fiber to the vapor phase (headspace) in equilibrium with the sample contained in a temperaturecontrolled flask, sealed with a perforable septum, and under stirring, as illustrated in Figure 5. Thus, substances are concentrated and adsorbed on the fiber, being directly desorbed on the gas chromatograph injector (ANGEROSA et al., 2004).

Olive oil is a complex matrix, containing volatile compounds of different chemical classes, with different physicochemical properties, such as volatility and polarity. Thus, it is expected that these different compounds have different equilibrium times. As the SPME technique is a multiphase equilibrium process, the tendency is a progressive enrichment of less volatile compounds with the increase in equilibrium time (CUI et al., 2009). It is expected that the combination of data from sensory analysis and those from organic volatile compounds would allow distinguishing cultivars and collection sites in order to be used as a distinctive sign for products.

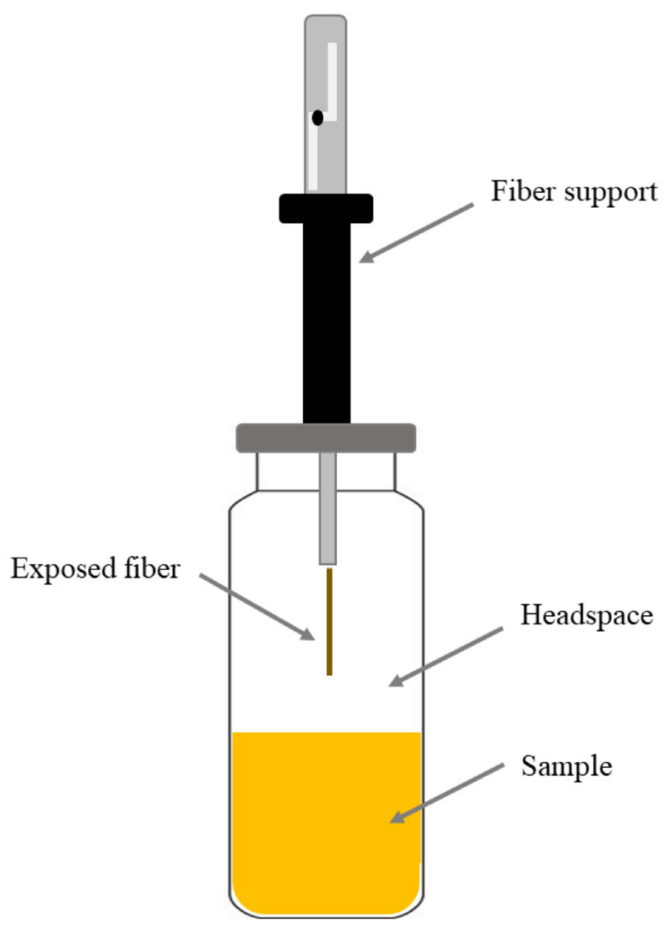

Figure 5. Representation of the procedure for extracting volatile compounds using the solid phase microextraction (SPME) technique (Source: Filoda, P.F).

\section{Concluding remarks}

The production of olive trees in Brazil is recent (mid-2003) and the knowledge about the crop is based on the performance of cultivars in traditional cultivation regions (Mediterranean Basin). However, it is necessary to generate knowledge from actual cultivation conditions, since different soils and climates found in different regions of Brazil provide different cultivation conditions and, consequently, different characteristics to olive oils. Thus, the measurements of olive oil quality variables can help determine the adaptability of cultivars to the local edaphic and climatic conditions, enabling producers to strengthen the identity of the products and adequately position them in the market.

\section{Acknowledgments}

This work was carried out with support from the Coordination for the Improvement of Higher Education Personnel - Brazil (CAPES) - Financing Code 001 (P.F. Filoda, scholarship), and from the National Council for Scientific and Technological Development (CNPq) (J.F. Hoffman, fellowship 312706/2020-0).

\section{References}

AGROLINK. Olivicultura pode ser oportunidade. 2020. Disponível em: https://www.agrolink.com.br/ noticias/olivicultura-pode-ser-oportunidade 440170. html. Acesso em: 20 out. 2020.

AGUILERA, M.P.; BELTRAN, G.; SANCHEZVILLASCLARAS, S.; UCEDA, M.; JIMENEZ, A. Kneading olive paste from unripe 'Picual' fruits: I. Effect on oil process yield. Journal of Food Engineering, London, v.97, n.4, p.533-538, 2010.

AKACHA, N.B.; GARGOURI, M. Enzymatic synthesis of green notes with hydroperoxide-lyase from olive leaves and alcohol-dehydrogenase from yeast in liquid/ gas reactor. Process Biochemistry, Barking, v.44, n.10, p.1122-1127, 2009.

AL-BACHIR, M.; SAHLOUL, H. Fatty acid profile of olive oil extracted from irradiated and non-irradiated olive fruits. International Journal of Food Properties, Philadelphia, v.20, n.11, p.2550-2558, 2017. 
ALAGNA, F.; MARIOTTI, R.; PANARA, F.; CAPORALI, S.; URBANI, S.; VENEZIANI, G., ESPOSTO, S.; TATICCHI, A.; ROSATI, A.; R.A.O, R.; BALDONI, L. Olive phenolic compounds: metabolic and transcriptional profiling during fruit development. BMC Plant Biology, London, v.12, n. 1, p. 162, 2012.

ALBA, J.M.F.; FLORES, C.A.; WREGE, M.S. Zoneamento edafoclimático da olivicultura para o Rio Grande do Sul. Brasília: Embrapa Clima Temperado, 2013. 70 p.

ALVES, E.; MELO, T.; REY, F.; MOREIRA, A.S.; DOMINGUES, P.; DOMINGUES, M.R. Polar lipid profiling of olive oils as a useful tool in helping to decipher their unique fingerprint. LWT -Food Science and Technology, Amsterdam, v.74, p.371-377, 2016.

ANGEROSA, F.; BASTI, C.; VITO, R. Virgin olive oil volatile compounds from lipoxygenase pathway and characterization of some Italian cultivars. Journal of Agricultural and Food Chemistry, Washington, v.47, n.3, p.836-839, 1999.

ANGEROSA, F.; CAMPESTRE, C.; GIANSANTE, L. Analysis and authentication. In: BOSKOU, D. Olive oil: chemistry and technology. Champaign: AOAC, 2006. p.113-172.

ANGEROSA, F.; SERVILI, M.; SELVAGGINI, R.; TATICCHI, A.; ESPOSTO, S.; MONTEDORO, G. Volatile compounds in virgin olive oil: occurrence and their relationship with the quality. Journal of Chromatography A, Amsterdam, v.1054, n.1-2, p.1731, 2004.

APARICIO, R.; LUNA, G. Characterisation of monovarietal virgin olive oils. European Journal of Lipid Science and Technology, Weinheim, v.104, n.910, p.614-627, 2002.

APARICIO, R.; MORALES, M.T.; GARCÍA GONZÁLEZ, D.L.Towards new analyses of aroma and volatiles to understand sensory perception of olive oil. European Journal of Lipid Science and Technologyy, Weinheimm v.114, n.10, p.1114-1125, 2012.

AUED-PIMENTEL, S.; TAKEMOTO, E.; KUMAGAI, E.E.; CANO, C.B. Determinação da diferença entre o valor real e o teórico do triglicerídeo ECN 42 para a detecção de adulteração em azeites de oliva comercializados no Brasil. Química Nova, São Paulo, v.31, n.1, p.31-34, 2008.
BALLUS, C.A.; MEINHART, A.D.; DE SOUZA CAMPOS JR, F.A.; DA SILVA, L.F.D.O.; DE OLIVEIRA, A.F.; GODOY, H.T. A quantitative study on the phenolic compound, tocopherol and fatty acid contents of monovarietal virgin olive oils produced in the southeast region of Brazil. Food Research International, New York, v.62, p.74-83, 2014.

BALLUS, C.A.; QUIRANTES-PINÉ, R.; BAKHOUCHE, A.; DA SILVA, L.F.D.O.; DE OLIVEIRA, A.F.; COUTINHO, E.F.; GODOY, H.T. Profile of phenolic compounds of Brazilian virgin olive oils by rapid resolution liquid chromatography coupled to electrospray ionisation time-of-flight mass spectrometry (RRLC-ESI-TOF-MS). Food Chemistry, London, v.170, p.366-377, 2015.

BAJOUB, A. Virgin olive oil: potential of different omics approaches to authenticate its geographical and botanical origin. 2016. Thesis (Doctor) - Universidad de Granada, Department of Analytical Chemistry, Granada, 2016.

BAJOUB, A.; CARRASCO-PANCORBO, A.; MAZA, G.B., FERNÁNDEZ-GUTIÉRREZ, A.; OUAZZANI, N. Contribution to the establishment of a protected designation of origin for Meknès virgin olive oil: A 4-years study of its typicality. Food Research International, New York, v.66, p.332-343, 2014.

BAJOUB, A.; CARRASCO-PANCORBO, A.; OUAZZANI, N.; FERNÁNDEZ-GUTIÉRREZ, A. Potential of LC-MS phenolic profiling combined with multivariate analysis as an approach for the determination of the geographical origin of north Moroccan virgin olive oils. Food Chemistry, London, v.166, p.292-300, 2015.

BAJOUB, A.; MEDINA-RODRÍGUEZ, S.; CUADROS-RODRÍGUEZ, L.; MONASTERIO, R.P.; VERCAMMEN, J.; FERNÁNDEZ-GUTIÉRREZ, A.; CARRASCO-PANCORBO, A. A metabolic fingerprinting approach based on selected ion flow tube mass spectrometry (SIFT-MS) and chemometrics: A reliable tool for Mediterranean origin-labeled olive oils authentication. Food Research International, New York, v.106, p.233-242, 2018.

BAJOUB, A.; SÁNCHEZ-ORTIZ, A.; OUAZZANI, N.; FERNÁNDEZ-GUTIÉRREZ, A.; BELTRÁN, G.; CARRASCO-PANCORBO, A. First comprehensive characterization of volatile profile of north Moroccan olive oils: a geographic discriminant approach. Food Research International, New York, v.76, p.410-417, 2015. 
BENDINI, A.; CERRETANI, L.; CARRASCOPANCORBO, A.; GÓMEZ-CARAVACA, A.M.; SEGURA-CARRETERO, A.; FERNÁNDEZGUTIÉRREZ, A., LERCKER, G. Phenolic molecules in virgin olive oils: a survey of their sensory properties, health effects, antioxidant activity and analytical methods.An overview of the last decade Alessandra. Molecules, Basel, v.12, n.8, p.1679-1719, 2007.

BIANCHI, G. Lipids and phenols in table olives. European Journal of Lipid Science and Technology, Weinheim, v.105, n.5, p.229-242, 2003.

BENDINI, A.; CERRETANI, L.; CARRASCOPANCORBO, A.; GÓMEZ-CARAVACA, A.M.; SEGURA-CARRETERO, A.; FERNÁNDEZGUTIÉRREZ, A.; LERCKER, G.Characterization of Arbequina virgin olive oils produced in different regions of Brazil and Spain: Physicochemical properties, oxidative stability and fatty acid profile. Food Chemistry, London, v.215, p.454-462, 2017.

BOSKOU, D. Olive oil: constituents, quality, health properties and bioconversions. London: BoD-Books on Demand, 2012. 500p.

BRASIL. Regulamento técnico para óleos vegetais, gorduras vegetais e creme vegetal. Resolução $n^{\circ} 270$, de 22 de setembro de 2005. Diário Oficial da União, Brasília, DF, v.184, p.372-373, 2005.

BRASIL. Regulamento técnico dos azeites de oliva e dos óleos de bagaço de oliva. Brasília, DF: Ministério da Agricultura, Pecuária e Abastecimento (MAPA). Diário Oficial da União, Brasília, DF, v.166, p.2-5, 2012.

BRENES, M.; GARCIA, A.; GARCIA, P.; GARRIDO, A. Acid hydrolysis of secoiridoid aglycons during storage of virgin olive oil. Journal of Agricultural and Food Chemistry, Washington, v.49, n.11, p.5609-5614, 2001.

BRUSCATTO, M.H.; ZAMBIAZI, R.C.; CRIZELCARDOSO, M.; PIATNICKI, C.M.S.; MENDONÇA, C.R.B.; DUTRA, F.L.G.; COUTINHO, E.F. Caracterização química e estabilidade oxidativa de azeites extraídos de oliveiras do Sul do Brasil. Pesquisa Agropecuária Brasileira, Brasília, DF, v.52, n.12, p.1231-1240, 2017.

CAJKA, T.; RIDDELLOVA, K.; KLIMANKOVA, E.; CERNA, M.; PUDIL, F.; HAJSLOVA, J. Traceability of olive oil based on volatiles pattern and multivariate analysis. Food Chemistry, London, v.121, n.1, p.282289, 2010.
CARDOSO, L.G.V.; BARCELOS, M.D.F.P.; DE OLIVEIRA, A.F.; PEREIRA, J.D.A.R.; DE ABREU, W.C.; DE ARAUJO PIMENTEL, F.; DE ANGELIS PEREIRA, M.C. Características físico-químicas e perfil de ácidos graxos de azeites obtidos de diferentes variedades de oliveiras introduzidas no Sul de Minas Gerais-Brasil. Semina: Ciências Agrárias, Londrina, v.31, n.1, p.127-135, 2010.

CARRASCO-PANCORBO, A.; CERRETANI, L.; BENDINI, A.; SEGURA-CARRETERO, A.; DEL CARLO, M.; GALLINA-TOSCHI, T.; FERNANDEZGUTIERREZ, A. Evaluation of the antioxidant capacity of individual phenolic compounds in virgin olive oil. Journal of Agricultural and Food Chemistry, Washington, v.53, n.23, p.8918-8925, 2005.

CAVALLI, J.F.; FERNANDEZ, X.; LIZZANICUVELIER, L.; LOISEAU, A.M. Comparison of static headspace, headspace solid phase microextraction, headspace sorptive extraction, and direct thermal desorption techniques on chemical composition of French olive oils. Journal of Agricultural and Food Chemistry, Washington, v.51, n.26, p.7709-7716, 2003.

CAYE, A.; RUFFONI, J.; ZIEGLER, D.D.R. Sistema setorial de inovação no agronegócio: uma análise para a produção de azeite de oliva no RS. Estudos Econômicos, São Paulo, v.37, n.75, p.75-105, 2020.

CECCHI, T.; ALFEI, B. Volatile profiles of Italian monovarietal extra virgin olive oils via HS-SPME-GCMS: Newly identified compounds, flavors molecular markers, and terpenic profile. Food Chemistry, London, v.141, n.3, p.2025-2035, 2013.

CICERALE, S.; LUCAS, L.; KEAST, R. Antimicrobial, antioxidant and anti-inflammatory phenolic activities in extra virgin olive oil. Current Opinion in Biotechnology, Oxford, v.23, n.2, p.129-135, 2012.

CRIADO, M.N.; MORELLÓ, J.R.; MOTILVA, M.J.; ROMERO, M.P. Effect of growing area on pigment and phenolic fractions of virgin olive oils of the Arbequina variety in Spain. Journal of the American Oil Chemists' Society, Oxford, v.81, n.7, p.633, 2004.

CRIZEL, R.L.; HOFFMANN, J.F.; ZANDONÁ, G.P.; LOBO, P.M.S.; JORGE, R.O; CHAVES, F.C. Characterization of extra virgin olive oil from southern Brazil. European Journal of Lipid Science and Technology, Weinheim, p.1900347, 2020. 
CUI, S.; TAN, S.; OUYANG, G.; JIANG, S.; PAWLISZYN, J. Headspace solid-phase microextraction gas chromatography-mass spectrometry analysis of Eupatorium odoratum extract as an oviposition repellent. Journal of Chromatography B, Amsterdan, v.877, n.20-21, p.1901-1906, 2009.

DA COSTA, E.B. Oliveiras avançam em terras capixabas: na safra 2020/21, a meta é produzir azeite genuinamente capixaba em escala comercial. Vitória: ES Brasil, 2019. 16 p. Disponível em: https://esbrasil. com.br/oliveiras-avancam-em-terras-capixabas/.

DACROCE, D.M.; BRUGNARA, E.C.; DE OLIVEIRA, V.P.; DIAS, C.R. Avaliação da produção e do rendimento de azeite das oliveiras 'Arbequina', 'Arbosana'e 'Koroneiki' em Santa Catarina. Agropecuária Catarinense, Florianópolis, v.29, n.1, p.54-57, 2016.

DA CROCE, D.M.; FLOSS, P.A.; DO ESPÍRITO SANTO, F.R.C.; RETT, H.T.; MATIAS, A.C. Características físico-químicas de azeite de oliva produzido em unidades experimentais de Santa Catarina. Agropecuária Catarinense, Florianópolis, v.25, n.2, p.39-41, 2012.

DASILVA, M.D.G.; FREITAS, A.M.C.; CABRITA, M.J.; GARCIA, R. Olive oil composition: volatile compounds. In: DIMITRIOS, B. (ed.). Olive oil: constituents, quality, health properties and bioconversions. London: Intech, 2012. p.500.

DA SILVEIRA, R.; VÁGULA, J.M.; DE LIMA FIGUEIREDO, I.; CLAUS, T.; GALUCH, M.B.; JUNIOR, O.O.S.; VISENTAINER, J.V. Rapid methodology via mass spectrometry to quantify addition of soybean oil in extra virgin olive oil: A comparison with traditional methods adopted by food industry to identify fraud. Food Research International, New York, v.102, p.43-50, 2017.

DABBOU, S.; ISSAOUI, M.; ESPOSTO, S.; SIFI, S.; TATICCHI, A.; SERVILI, M.; HAMMAMI, M. Cultivar and growing area effects on minor compounds of olive oil from autochthonous and European introduced cultivars in Tunisia. Journal of the Science of Food and Agriculture, New York, v.89, n.8, p.1314-1325, 2009.

DAG, A.; KEREM, Z.; YOGEV, N.; ZIPORI, I., LAVEE, S.; BEN-DAVID, E. Influence of time of harvest and maturity index on olive oil yield and quality. Scientia Horticulturae, Wageningen, v.127, n.3, p.358-366, 2011.
DAĞDELEN, A.; TÜMEN, G.; ÖZCAN, M.M.; DÜNDAR, E. Phenolics profiles of olive fruits (Olea europaea L.) and oils from Ayvalık, Domat and Gemlik varieties at different ripening stages. Food Chemistry, London, v.136, n.1, p.41-45, 2013.

DE OLIVEIRA, A.F.; NETO, J.V.; GONÇALVES, E.D.; VILLA, F.; DA SILVA, L.F.D.O. Parâmetros físico-químicos dos primeiros azeites de oliva brasileiros extraídos em Maria da Fé, Minas Gerais. Scientia Agraria, Curitiba, v.11, n.3, p.255-261, 2010.

DROSSOPOULOS, J.; NIAVIS, C. Seasonal changes of the metabolites in the leaves, bark and xylem tissues of olive tree (Olea europaea.L) II. Carbohydrates. Annals of Botany, London, v.62, n.3, p.321-327, 1988.

DUDAREVA, N.; NEGRE, F.; NAGEGOWDA, D.A.; ORLOVA, I. Plant volatiles: recent advances and future perspectives. Critical Reviews in Plant Sciences, Lodon, v.25, n.5, p.417-440, 2006.

EL RIACHY, M.; PRIEGO CAPOTE, F.; LEÓN, L.; RALLO, L.; LUQUE DE CASTRO, M.D. Hydrophilic antioxidants of virgin olive oil.Part 1: Hydrophilic phenols: A key factor for virgin olive oil quality. European Journal of Lipid Science and Technology, Weinheim, v.113, n.6, p.678-691, 2011.

EPAMIG. Azeitona e azeite de oliva: tecnologias de produção. Informe Agropecuário, Belo Horizonte, v.27, n.231, p.104, 2006.

FLORES, G.; DEL CASTILLO, M.L.R.; HERRAIZ, M.; BLANCH, G.P. Study of the adulteration of olive oil with hazelnut oil by on-line coupled high performance liquid chromatographic and gas chromatographic analysis of filbertone. Food Chemistry, London, v.97, n.4, p.742749, 2006.

FLORIPA, T.S. Rancho queimado: empresa é pioneira na produção do azeite de oliva com fins comerciais. Florianópolis, 2019. Disponível em: http://www. tudosobrefloripa.com.br/index.php/desc_noticias/ rancho queimado empresa e pioneira na producaeo do_azeite de oliva com fins. Acesso em: 05 mar. 2021.

GARCIA, S.R.; DOS SANTOS, D.F.; MARTINS, F.B.; TORRES, R.R. Aspectos climatológicos associados ao cultivo da oliveira (Olea europaea L.) em Minas Gerais. Revista Brasileira de Climatologia, São Paulo, v.22, p.188-206, 2018. 
GÓMEZ-RICO, A.; SALVADOR, M.D.; FREGAPANE, G. Virgin olive oil and olive fruit minor constituents as affected by irrigation management based on SWP and TDF as compared to ETc in medium-density young olive orchards (Olea europaea L. cv. Cornicabra and Morisca). Food Research International, New York, v.42, n.8, p.1067-1076, 2009.

GUASCH-FERRÉ, M.; LIU, G.; LI, Y.; SAMPSON, L.; MANSON, J.E.; SALAS-SALVADÓ, J.; MARTÍNEZGONZÁLEZ, M.A.; STAMPFER, M.J.; WILLETT, W.C.; SUN, Q. Olive oil consumption and cardiovascular risk in US adults. Journal of the American College of Cardiology, New York, v.75, n.15, p.1729-1739, 2020.

IBRAOLIVA - Instituto Brasileiro de Olivicultura. Abertura oficial da colheita da oliva será em Caçapava do Sul. 2020. Disponível em: https://www. ibraoliva.com.br/noticias/detalhe/77/abertura-oficial-dacolheita-da-oliva-sera-em-cacapava-do-sul. Acesso em: 04 mar. 2020.

INGLESE, P.; FAMIANI, F.; GALVANO, F.; SERVILI, M.; ESPOSTO, S.; URBANI, S. Factors affecting extravirgin olive oil composition. Horticultural Reviews, New York, v.38, p.83, 2011.

IOC - International Olive Council. Trade standard applying to olive oil and olive-pomace oil. Madrid, 2013. (COI/T.15/NC No 3/Rev.7)

IOC - International Olive Council. International olive figures. Madrid, 2020. Disponível em: www. internationaloliveoil.org/estaticos/view/131-worldolive-oil-figures. Acesso em: 05 mar. 2020.

KALOGIOURI, N.P.; ALYGIZAKIS, N.A,; AALIZADEH, R.; THOMAIDIS, N.S. Olive oil authenticity studies by target and nontarget LC-QTOFMS combined with advanced chemometric techniques. Analytical and Bioanalytical Chemistry, Heidelberg, v.408, n.28, p.7955-7970, 2016.

KALUA, C.M.; ALLEN, M.S.; BEDGOOD JR., D.R.; BISHOP, A.G.; PRENZLER, P.D.; ROBARDS, K. Olive oil volatile compounds, flavour development and quality: A critical review. Food Chemistry, London, v.100, n.1, p.273-286, 2007.
KALUA, C.M.; ALLEN, M.S.; BEDGOOD, D.R.; BISHOP, A.G.; PRENZLER, PD. Discrimination of olive oils and fruits into cultivars and maturity stages based on phenolic and volatile compounds. Journal of Agricultural and Food Chemistry, Washington, v.53, n.20, p.8054-8062, 2005.

KAPELLAKIS, I.E.; TSAGARAKIS, K.P.; CROWTHER, J.C. Olive oil history, production and by-product management. Reviews in Environmental Science and Bio/Technology, Amsterdam, v.7, n.1, p.1-26, 2008.

KARBAN, R. Plant behaviour and communication. Ecology Letters, Oxford, v.11, n.7, p.727-739, 2008.

KIST, B.B.; DE CARVALHO, C.; BELING, R.R. Anuário brasileiro das oliveiras. 2.ed. Santa Cruz: Editora Gazeta, 2019. 56 p.

KOIDIS, A.; BOSKOU, D. The contents of proteins and phospholipids in cloudy (veiled) virgin olive oils. European Journal of Lipid Science and Technology, Weinheim, v.108, n.4, p.323-328, 2006.

LANTERI, S.; ARMANINO, C.; PERRI, E.; PALOPOLI, A. Study of oils from Calabrian olive cultivars by chemometric methods. Food Chemistry, London, v.76, n.4, p.501-507, 2002.

LANZA, B.; DI SERIO, M.G. Characterization of olive (Olea europaea L.) fruit epicuticular waxes and epicarp. Scientia Horticulturae, Wageningen, v.191, p.49-56, 2015.

LUNA, G.; MORALES, M.; APARICIO, R. Characterisation of 39 varietal virgin olive oils by their volatile compositions. Food Chemistry, London, v.98, n.2, p.243-252, 2006.

MAGGIO, R.M.; KAUFMAN, T.S.; DEL CARLO, M.; CERRETANI, L.; BENDINI, A.; CICHELLI, A.; COMPAGNONE, D. Monitoring of fatty acid composition in virgin olive oil by Fourier transformed infrared spectroscopy coupled with partial least squares. Food Chemistry, London, v.114, n.4, p.1549-1554, 2009.

MAILER, R.J.; AYTON, J.; GRAHAM, K. The influence of growing region, cultivar and harvest timing on the diversity of Australian olive oil. Journal of the American Oil Chemists' Society, Champaign, v.87, n. 8, p. $877-884,2010$. 
MALHEIRO, R.; RODRIGUES, N.; PEREIRA, J.A. Olive oil phenolic composition as affected by geographic origin, olive cultivar, and cultivation systems. In: BOSKOU, D. Olive and olive oil bioactive constituents. London: AOCS Pres, 2015. p.93-121.

MARSILIO, V.; CAMPESTRE, C.; LANZA, B.; DE ANGELIS, M. Sugar and polyol compositions of some European olive fruit varieties (Olea europaea L.) suitable for table olive purposes. Food Chemistry, London, v.72, n.4, p.485-490, 2001.

MARTINS, F.B.; PEREIRA, R.A.D.A.; TORRES, R.R.; SANTOS, D.F.D. Climate projections of chill hours and implications for olive cultivation in Minas Gerais, Brazil. Pesquisa Agropecuária Brasileira, Brasília, DF, v.55, p.e01852, 2020.

MEDEIROS, R.M.L.; VILLA, F.; DA SILVA, D.F.; CARDOSO FILHO, L.R. Destinação e reaproveitamento de subprodutos da extração olivícola. Scientia Agraria Paranaensis, Cascavel, v.15, n.2, p.100-108, 2016.

MEDINA, E.; DE CASTRO, A.; ROMERO, C.; BRENES, M. Comparison of the concentrations of phenolic compounds in olive oils and other plant oils: correlation with antimicrobial activity. Journal of Agricultural and Food Chemistry, Washington, v.54, n.14, p.4954-4961, 2006.

MELLO, L.D.; PINHEIRO, M.F. Aspectos físicoquímicos de azeites de oliva e de folhas de oliveira provenientes de cultivares do RS, Brasil. Alimentos e Nutrição, São Paulo, v.23, n.4, p.537-548, 2012.

MENAL-PUEY, S.; MARTÍNEZ-BIARGE, M.; MARQUES-LOPES, I. Developing a food exchange system for meal planning in vegan children and adolescents. Nutrients, Basel, v.11, n.1, p.43, 2019.

MINAS, A. Primeiro azeite extravirgem da Chapada Diamantina é produzido com tecnologia Epamig. Belo Horizonte, 2021. Disponível em: http://www. agenciaminas.mg.gov.br/noticia/primeiro-azeiteextravirgem-da-chapada-diamantina-e-produzido-comtecnologia-epamig. Acesso em: 05 mar. 2021.

MORAL, P.S.; MÉNDEZ, M.V.R. Production of pomace olive oil. Grasas y Aceites, Madrid, v.57, n.1, p.47-55, 2006.
NACZK, M.; SHAHIDI, F. Extraction and analysis of phenolics in food. Journal of Chromatography A, Amsterdam, v.1054, n.1-2, p.95-111, 2004.

OUNI, Y.; TAAMALLI, A.; GÓMEZ-CARAVACA, A.M.; SEGURA-CARRETERO, A.; FERNÁNDEZGUTIÉRREZ, A.; ZARROUK, M. Characterisation and quantification of phenolic compounds of extra-virgin olive oils according to their geographical origin by a rapid and resolutive LC-ESI-TOF MS method. Food Chemistry, London, v.127, n.3, p.1263-1267, 2011.

POULIAREKOU, E.; BADEKA, A.; TASIOULAMARGARI, M.; KONTAKOS, S.; LONGOBARDI, F.; KONTOMINAS, M.G. Characterization and classification of Western Greek olive oils according to cultivar and geographical origin based on volatile compounds. Journal of Chromatography A, Amsterdam, v.1218, n.42, p.7534-7542, 2011.

PROCIDA, G.; CICHELLI, A.; LAGAZIO, C.; CONTE, L.S. Relationships between volatile compounds and sensory characteristics in virgin olive oil by analytical and chemometric approaches. Journal of the Science of Food and Agriculture, New York, v.96, n.1, p.311$318,2016$.

PROCIDA, G.; GIOMO, A.; CICHELLI, A.; CONTE, L.S. Study of volatile compounds of defective virgin olive oils and sensory evaluation: a chemometric approach. Journal of the Science of Food and Agriculture, New York, v.85, n.13, p.2175-2183, 2005.

RALLO, L.; DÍEZ, C.M.; MORALES-SILLERO, A.; MIHO, H.; PRIEGO-CAPOTE, F.; RALLO, P. Quality of olives: A focus on agricultural preharvest factors. Scientia Horticulturae, Wageningen, v.233, p.491-509, 2018.

RANALLI, A.; MALFATTI, A.; LUCERA, L.; CONTENTO, S.; SOTIRIOU, E. Effects of processing techniques on the natural colourings and the other functional constituents in virgin olive oil. Food Research International, New York, v.38, n.8-9, p.873878, 2005.

ROMERO, I.G.; GARCÍA-GONZÁLEZ, D.L.; APARICIO-RUIZ, R.; MORALES, M.T. Validation of SPME-GCMS method for the analysis of virgin olive oil volatiles responsible for sensory defects. Talanta, New York, v.134, p.394-401, 2015. 
ROMERO, N.; SAAVEDRA, J.;TAPIA, F.; SEPÚLVEDA, B.; APARICIO, R.Influence of agroclimatic parameters on phenolic and volatile compounds of Chilean virgin olive oils and characterization based on geographical origin, cultivar and ripening stage. Journal of the Science of Food and Agriculture, New York, v.96, n.2, p.583-592, 2016.

ROYO, J. Projeto pioneiro inicia cultivo de oliveiras em Santa Catarina. Florianópolis: Epagri, 2010. Disponível em: http://diadecampo.com.br/zpublisher/ materias/Materia.asp?id $=21249 \&$ secao $=$ Pacotes $\% 20$ Tecnol\%F3gicos\&t=EPAGRI . Acesso em: 05 mar. 2021.

RYAN, D.; ROBARDS, K. Critical review. Phenolic compounds in olives. Analyst, New York, v.123, n.5, p.31R-44R, 1998.

SÁ, D.; CAMPOS, R.D.S.; DE FARIA-MACHADO, A. Aceitação de azeites de oliva da Região da Mantiqueira (MG): entendendo consumidor e azeite brasileiros. Rio de Janeiro: Embrapa Agroindústria de Alimentos, 2019. (Documentos INFOTECA-E)

SALVADOR, M.; ARANDA, F.; FREGAPANE, G. Influence of fruit ripening on 'Cornicabra'virgin olive oil quality a study of four successive crop seasons. Food Chemistry, London, v.73, n.1, p.45-53, 2001.

SANTO, G.D.E. O cultivo de oliveiras para a produção de azeite é apresentado na Assembleia Legislativa. 2019. Disponível em: https://www.es.gov. br/Noticia/o-cultivo-e-oliveiras-para-a-producao-deazeite-e-apresentado-na-assembleia-legislativa. Acesso em: 05 mar. 2021.

SERVILI, M.; ESPOSTO, S.; FABIANI, R.; URBANI, S.; TATICCHI, A.; MARIUCCI, F.; SELVAGGINI, R.; MONTEDORO, G.F. Phenolic compounds in olive oil: antioxidant, health and organoleptic activities according to their chemical structure. Inflammopharmacology, Dordrecht, v.17, n.2, p.76-84, 2009.

SERVILI, M.; ESPOSTO, S.; LODOLINI, E.; SELVAGGINI, R.; TATICCHI, A.; URBANI, S.; MONTEDORO, G.; SERRAVALLE, M.; GUCCI, R. Irrigation effects on quality, phenolic composition, and selected volatiles of virgin olive oils cv.Leccino. Journal of Agricultural and Food Chemistry, Washington,v.55, n.16, p.6609-6618, 2007.
SERVILI, M.; ESPOSTO, S.; TATICCHI, A.; URBANI, S.; DI MAIO, I.; VENEZIANI, G.; SELVAGGINI, R. New approaches to virgin olive oil quality, technology, and by products valorization. European Journal of Lipid Science and Technology, Weinheim, v.117, n.11, p.1882-1892, 2015.

SERVILI, M.; SELVAGGINI, R.; ESPOSTO, S.; TATICCHI, A.; MONTEDORO, G.; MOROZZI, G. Health and sensory properties of virgin olive oil hydrophilic phenols: agronomic and technological aspects of production that affect their occurrence in the oil. Journal of Chromatography A, Amsterdam, v.1054, n.1-2, p.113-127, 2004.

SERVILI, M.; SORDINI, B.; ESPOSTO, S.; TATICCHI, A.; URBANI, S.; SEBASTIANI, L. Metabolomics of olive fruit: a focus on the secondary metabolites. In: RUGINI, E.; BALDANI, L.; MULEO, R.; SEBASTIANI, L. (ed.). The olive tree genome. Berlin: Springer, 2016. p.123-139.

SIMÕES, F.R.M.M. Zoneamento agroclimático e as possibilidades para a olivicultura no estado do Paraná. 2016. Monografia (Trabalho de Conclusão de Curso Bacharelado em Geografia) - Universidade Estadual Paulista, Câmpus Experimental de Ourinhos, 2016.

SOUILEM, S.; EL-ABBASSI, A.; KIAI, H.; HAFIDI, A.; SAYADI, S.; GALANAKIS, C.M. Olive oil production sector: environmental effects and sustainability challenges. In: GALANAKIS, C.M. (ed.). Olive mill waste. Oxford: Academic Press: 2017. p.1-28

TAIZ, L.; ZEIGER, E.; MOLLER, I.M.; MURPHY, A. Fisiologia e desenvolvimento vegetal. Porto Alegre: Artmed Editora, 2017.

TEMIME, S.B.; CAMPEOL, E.; CIONI, P.L.; DAOUD, D.; ZARROUK, M. Volatile compounds from Chétoui olive oil and variations induced by growing area. Food Chemistry, London, v.99, n.2, p.315-325, 2006.

TURA, D.; GIGLIOTTI, C.; PEDO, S.; FAILLA, O.; BASSI, D.; SERRAIOCCO, A. Influence of cultivar and site of cultivation on levels of lipophilic and hydrophilic antioxidants in virgin olive oils (Olea europea L.) and correlations with oxidative stability. Scientia Horticulturae, Wageningen, v.112, n.1, p.108-119, 2007. 
VLACHOS, N.; SKOPELITIS, Y.; PSAROUDAKI, M.; KONSTANTINIDOU, V.; CHATZILAZAROU, A.; TEGOU, E. Applications of Fourier transform-infrared spectroscopy to edible oils. Analytica Chimica Acta, Amsterdam, v.573, p.459-465, 2006.

WREGE, M.S.; COUTINHO, E.F.; PANTANO, A.P.; JORGE, R.O. Distribuição potencial de oliveiras no Brasil e no mundo. Revista Brasileira de Fruticultura, Jaboticabal, v.37, n.3, p.656-666, 2015.
OUNI, Y.; TAAMALLI, A.; GÓMEZ-CARAVACA, A.M.; SEGURA-CARRETERO, A.; FERNÁNDEZGUTIÉRREZ, A.; ZARROUK, M. Volatile compounds and compositional quality of virgin olive oil from Oueslati variety: Influence of geographical origin. Food Chemistry, London, v.124, n.4, p.1770-1776, 2011.

ZAGO, L.; SQUEO, G.; BERTONCINI, E.I.; DIFONZO, G.; CAPONIO, F. Chemical and sensory characterization of Brazilian virgin olive oils. Food Research International, New York, v.126, p.108588, 2019. 